CASE STUDY

\title{
Eastern Partnership: Advocating for Economic Growth and Competitiveness
}

\author{
Rusu L* \\ Studies, Romania. \\ *Corresponding Author: E-Mail: livia_rusu@hotmail.com
}

Institute of Doctoral Studies, Department of International Business and Economics, Bucharest Academy of Economic

\begin{abstract}
During past years, the debate on the topic of Eastern European Union frontier has been high on the international agenda. The policy reaction envisaged by the European Union following the enlargement process generated various feelings: from appreciation to doubt or sometimes even disappointment. The most recent initiative is represented by the Eastern Partnership. This study tries to inquire if the Eastern Partnership project responds to a certain extent to the needs of the addressees in terms of supporting their economic growth and promoting greater international competitiveness. The different approach represented by this study resides in a comparison between two separated tools, both either dealing with or including references to same objects of interest: namely, economic performances of Eastern European countries. The main contribution is given by the clarity and the transparency of the method; it also furnishes simple and unambiguous suggestions for further actions.
\end{abstract}

Keywords: Competitive economies, Eastern partnership, Global competitiveness factors.

\section{Introduction}

When Eastern Partnership was launched back in 2009 at the Prague Summit, the aim envisaged by this European Union (EU) initiative for the six partner countries (Armenia, Azerbaijan, Belarus, Georgia, Republic of Moldova and Ukraine) consisted, basically, in providing additional and more specific support for reforms and modernization with a view to increase all standards and to strengthen and secure stability and prosperity at the EU borders [1]. In 2011, as agreed at the Prague Summit, an Eastern Partnership Roadmap (together with two tables) was proposed with a view to guide and to monitor the work undertaken for the implementation of the bilateral and multilateral dimensions in the perspective of the third Summit to take place in autumn 2013. The common work EU and partner countries is supposed to be concentrated on those aspects requiring decisive action in order to ensure a solid foundation for sustainable and inclusive economic growth, but also a sound and functioning democracy. In this way, the conditions to accelerate political association and deepen economic integration between the two actors would have been created [2]. The recent outlook on the performances registered by the world economies underlines the improvements necessitated by states for stable economic growth on medium and longer term, hence for increased global competitiveness and better productivity.

Taking all the above into account, the main purpose of this research is to inquire if the offer made by the EU under the Eastern Partnership umbrella covers the domains or the sectors where those countries' economies need further and deeper transformations. In other words, the question is: does the substance of the EU offer represent what partners need for economic growth, higher productivity and improved international competitiveness? Equally, the study attempts to suggest areas of possible high interest for an enhanced dialogue between the EU and its Eastern neighbours. As long as a concrete implication of Belarus in the Eastern Partnership projects and programmes is correlated with the political evolutions in this country [3], the present paper encompasses the remaining five states (Armenia, Azerbaijan, Georgia, Republic of Moldova and Ukraine).

\section{Outlook on Global Competitiveness}

As a general note, it can be noticed that the area concerned includes countries considered amongst the least European competitive economies; however, the disparities in competitiveness for 
these countries in particular are not highly significant. A closer glance would reveal that the problems the EU Eastern partners encounter are similar, even if they may affect the countries on different degrees. This justifies an approach both country specific (bilateral), designated to tackle the precise challenges an economy may run into, as well as multilateral, meant to regionally address the economic environment where actors interact. A positive aspect for all these countries is given by the achievement of annual economic growth in 2011, the rates being overall higher the ones obtained by some developed EU member states (the champion is Georgia with $7 \%$ annual GDP growth, followed by R. of Moldova with $6.4 \%$, Ukraine 5.2\%, Armenia 4.6\% and Azerbaijan 1\%) [4].

In terms of global competitiveness (Global Competitiveness Index), Armenia ranks $82^{\text {nd }}$ out of 144 world economies, succeeding to become in 2012 an efficiency-driven economy. The most noticeable progress was registered in the field of institutions (ranked $16^{\text {th }}$ concerning the transparency of government policymaking, $8^{\text {th }}$ regarding the business costs of terrorism, $31^{\text {st }}$ on government services for improved business performance, $41^{\text {st }}$ on the burden of government regulation). Still, efforts need to continue on ensuring the judicial independence (ranked 110th), improving the reliability of police services (ranked 93rd), reducing the irregular payments and bribes (ranked 82nd). The competitive advantage of Armenia relies in the area of labor market efficiency (hiring and firing practices, flexibility of wage determination, pay and productivity or cooperation in labor-employer relations). The goods and services market lacks the intensity of local competition (130th) and is affected by the inefficiency of anti-monopoly policies (116th), the burden of the custom procedures (127th) or the prevalence of trade barriers (99th). Changes would be welcomed in the domain of financial market development (for instance, improving the financing through local equity market currently on 115th). The poor performance of the higher education and training (70th) and primary education sectors (108th) generates a low development of the innovation capacity of the country (ranked 105th) [5].

Azerbaijan ranks $46^{\text {th }}$ in the world competitiveness classification, but the advance based on a very good macroeconomic environment ( $5^{\text {th }}$ place for the government budget balance and $8^{\text {th }}$ for the gross national savings due to the high energy exports) cannot provide a step forward beyond the stage of transition economy from factor-driven to efficiency-driven. A quite fair situation in the labor market is not sufficient to compensate the fragile higher education and training (ranked 89th) or the low health and primary education (107th); also weak is the development in the financial market (place 98th), where the most problematic are the soundness of bank system (133rd) and the availability of financial services (119th). The institution pillar requires reforms in the field of decreasing the irregular payments and bribes (110th) and improving the judicial independence (86th), while the goods market could gain from a better local competition (131st), an effective anti-monopoly policy (114th) or a process of elimination of trade barriers and custom procedures (107th). The innovation capacity benefits from the financial resources available from the energy exports [5].

A remarkable evolution is registered in 2012 by Georgia (ranked as $77^{\text {th }}$ world competitive economy, a leap of 11 places compared to 2011), the progresses allowing the upgrade to the development stage of efficiency-driven economy. In terms of institutions, even if reforms have been conducted, there is still room for pursuing with changes, particularly on strengthening the judicial independence (95th) or ensuring the efficiency of legal framework in challenging regulations (106th). Labor market enjoys a fair situation, even if the brain drain phenomena (104th) could have a negative impact on medium and long term. As the country moved to a more advanced stage of economic development, it needs improvement in a higher education and training (93rd), as well as advancement in the goods and services market (anti-monopoly policy, better local competition, agricultural policy costs) and in the financial market (local financing for firms, availability of financial services, soundness of banks). It also lacks innovation capacity (126th) and business sophistication [5].

Republic of Moldova remains a factor-driven economy, meaning that the $87^{\text {th }}$ place in the international competitiveness classification (even if progressed compared to last year $93^{\text {rd }}$ place) is not enough for an upgrade in its development stage. The institutional domain (ranked 110th) asks for steady reforms on a wide range of areas (ensuring judicial independence, cutting favoritisms in decisions of government officials, easing the burden of government regulation, reducing the corruption). The most competitive advantage is given by the labor market, but the level in higher training and education (88th) and the brain drain phenomena (137th) could 
determine unconstructive consequences. The goods market (where the agricultural policy costs present a real challenge) and the financial market need improvements. A boost to the innovation sector (135th) is difficult to be realized should other sectors do not achieve appropriate adjustments [5].

As a consequence of a healthier macroeconomic environment after the economic crisis, Ukraine jumps to $73^{\text {rd }}$ position in the global competitiveness, obtaining in 2012 the feature of efficiency-driven economy. In terms of institutional framework (132nd), Ukraine offers the poorest performance amongst these countries; it clearly misses a decisive input in the direction of improving the efficiency of legal framework in settling disputes (141st out of 144 economies), increasing judicial independence (124th), reducing the burden of government regulation (135th), diminishing irregular payments and bribes (133rd) or improving the transparency of government policymaking (123rd). The country's competitive position could be enhanced by reforms in the goods and services market (eliminating the burden of custom procedures, the trade barriers, ensuring fair agricultural costs, applying effective anti-monopoly policies, controlling the taxation, improving the intensity of local competition) and in the financial market (developing the financing through local equity market or ensuring the soundness of bank system and the availability and affordability of financial services). The competitive strengths consist in a large market size (ranked 38th) and a strong educational system (47th place for higher education and training and 62nd for health and primary education). This last aspect determines a quite relevant innovation capacity (71st). A worrying indicator is represented by the brain drain phenomena (ranked 131st). [5]

A series of issues (common to all states, but affecting them on various degrees) identified by the investors as the most problematic factors for doing business can be pointed out: corruption, inefficient government bureaucracy, access to financing, tax regulations, inadequately educated workforce, tax rates, inadequately supply of infrastructure, inflation, foreign currency regulations, insufficient capacity to innovate, poor work ethic in national labor force, restrictive labor regulations, government instability/coups, policy instability, poor public health, crime and theft. [5]

\section{Towards the 2013 Deadline}

Another observation drawn from the above analysis is that the stage of development of each country and the level attained so far in international competitiveness reveal the weaknesses and strengths of those economies, indicating the areas that require transformations in order to build up a solid ground for further economic growth and better competitiveness. It would be interesting to see if these fields are overlapping or it could be correlated with the domains of action foreseen in the eve of the 2013 Eastern Partnership Summit. The central idea behind the rationale of doing this resides in the consideration that every country strives to obtain the necessary conditions (the basic requirements, the enhancement factors, the innovation and sophistication factors) that would lead to greater competitiveness and steady economic growth.

At bilateral level, the measures to be undertaken by Eastern states appear to be reflected in the provisions of the European Neighborhood Action Plans (or Association Agenda in the case of Ukraine) and reiterated in the Association Agreements, currently under negotiation. The institutional framework is particularly highlighted, the desired actions seeking to cover a wide array of problems: rule of law administered by an independent and impartial judiciary, fight against corruption, reform of the security and law enforcement sectors (including the police), respect for human rights and fundamental freedoms, regulatory approximation and capacity building, planning of institution strengthening and others. [6] Basically, the fulfillment of all these measures would help the states to progress on the basic requirements pillar and enhance their global competitiveness. For R. of Moldova in particular, the effect could consist in an upgrade to the next stage of economic development, if combined with few steps forward on higher education and training, goods market and labor market sectors. For Ukraine, the consequence could translate in a jump to a superior rank, away from the actual 132nd position out of 144 world economies. As part of Association Agreements, the establishment of a Deep and Comprehensive Free Trade Area (documents under discussion with all countries except Azerbaijan that prior needs to become a WTO member and Ukraine that already finalized it) could generate a positive impact on the goods market domain and not only. For instance, it could allow continued trade related reforms (removing barriers, boosting competition and financial services) and also improve the business and investments climate [6].

The bilateral interaction provides room for a dialogue on migration policy, including aspects related to the brain drain phenomena (even if perhaps the measures envisaged can be more decisive). The mobility is addressed through Visa Facilitation and Readmission Agreements (visa dialogue and negotiation and implementation of 
visa liberalization Action Plans) and Mobility Partnerships. The support in fighting against organised crime, against financial crime including terrorism financing, tackling illicit drugs is also foreseen [6]; the impact of some palpable results would be felt on the competitiveness basic requirements pillar.

The bilateral sector cooperation should allow the involvement of Eastern states in EU programmes and agencies. A more concrete input for a comprehensive development of the wide infrastructure domain could be noticed; the proposed measures in the energy field (meant to improve the quality of energy supply and ensure its efficiency) and concerning transport networks (air and maritime, less road though) may prove useful for a further enhancement of the competitiveness basic requirements pillar.

As indicated by the status in the global competitiveness factors, there are some areas that require some real intervention and support. One of them refers to the agricultural and rural development. All countries need expertise, new approaches and strategies towards agriculture development. For the first time, the sector is addressed, but it will take time for tangible results. Other two relevant domains are foreseen for the bilateral dimension: cooperation on macroeconomic and financial stability issues and regarding labor market (employment and social policies). As structural reforms are expected in these fields for all world economies (with consequences generating in the end the green light for further economic growth and increased competitiveness), a possible and constant association of Eastern countries to the evolutions and decisions in these areas appears well justified and most needed.

The bilateral cooperation under the Eastern Partnership is supposed to be complemented by a multilateral interaction, embracing the form of Platforms on thematic issues (democracy, good governance and stability; economic developments; energy security; facilitating contacts between people) accompanied by flagship initiatives (Integrated Border Management; Prevention of, Preparedness for, and Response to natural and man-made disasters; Small and Medium-sized Enterprises; Regional Electricity Markets, Energy Efficiency and Renewable Energy) and specific expert Panels [7]. The first Platform and its associated instruments (including the Panel on Public Administration Reform, the one on Improved Functioning of the Judiciary, the one on Fight against Corruption, the one on Migration and Asylum or the various seminars, workshops and training courses) should enhance the institutions pillar, increasing the competitive advantage of the partner countries in this area. The second Platform is destined to complement the bilateral actions undertaken for the goods market development (Panel on Trade and TradeRelated Regulatory Cooperation), for the labor market and social policies (dialogue begun in 2012 with initial conclusions during first half of 2013), macroeconomic stability, transport infrastructure (Panel on Transport), statistics and business environment (Panel on Small and Medium Enterprises policy). The innovation domain could probably be enhanced by a Panel on Industrial Innovation, while a higher involvement in the EU $7^{\text {th }}$ Research Framework Programme may prove valuable for building research capacity in the perspective of setting up of a Common Knowledge and Innovation Space. However, this last aspect cannot be functional without a serious improvement in the higher education and training levels and without a modernization of educational systems (sector also in need of structural changes and new approaches, linked with the labor market reform subject). The Business Forum is expected to contribute with concrete suggestions and measures of action to the improvement of business and investments climate.

\section{Conclusions}

Following the above analysis, the main observation that could be drawn resides in the idea that, in general, the offer made by EU to Armenia, Azerbaijan, Georgia, Republic of Moldova and Ukraine, under the Eastern Partnership umbrella, covers the core domains or the sectors where those countries' economies need further and deeper transformations. There are some areas where the current level of competitiveness gained by each economy suggests a rather urgent and preeminent intervention: agriculture sector (policy costs and, ultimately, food prices), labor market (social policies, as well as the brain drain theme), macroeconomic and financial stability issues (the question should also be high on the agenda due to its impact or relevance for the present global environment). Not the least, these represent topics of high importance in the ongoing international debate. The support envisaged by EU appears to be quite well targeted for the objective of building up a solid foundation for sustainable and inclusive economic growth; the results, however, depend on each country's performance and determination to pursue the necessary steps to achieve a stable economic growth and increased international competitiveness. The extent to which very country succeeds to do it could be the object of a separate study. 


\section{References}

1. Joint Declaration of the Prague Eastern Partnership Summit (2009), http://www.consilium.europa.eu/uedocs/cms_data/do cs/pressdata/en/er/107589.pdf accessed on 9 October, 2012.

2. Joint Communication to the European Parliament, the Council, the European Economic and Social Committee and the Committee of the Regions, Eastern Partnership: A Roadmap to the autumn 2013 Summit, JOIN(2012) 13 final, http://ec.europa.eu/world/enp/docs/2012_enp_pack/e _pship_roadmap_en.pdf accessed on 10 October, 2012.

3. Remarks by HRVP Catherine Ashton at the presentation of the ENP package (2012), Brussels, 15 May, http://europa.eu/rapid/pressrelease_MEMO-12-352_en.htm accessed on 13 October, 2012.

4. World Bank Data Base, accessed on 19 September, 2012.

5. The Global Competitiveness Report 2012-2013, World Economic Forum (2012): 13-20, 92-93, 98-99, 174-175, 258-259, 354-355.
6. Joint Staff Working Document, Eastern Partnership Roadmap 2012-13: The Bilateral Dimension accompanying the document Joint Communication to the European Parliament, the Council, the European Economic and Social Committee and the Committee of the Regions, Eastern Partnership: A Roadmap to the autumn 2013 Summit SWD(2012) 109 final, http://ec.europa.eu/world/enp/docs/2012_enp_pack/e _pship_bilateral_en.pdf accessed on 14 October, 2012.

7. Joint Staff Working Document, Eastern Partnership Roadmap 2012-13: The Multilateral Dimension accompanying the document Joint Communication to the European Parliament, the Council, the European Economic and Social Committee and the Committee of the Regions, Eastern Partnership: A Roadmap to the autumn 2013 Summit $\operatorname{SWD}(2012) \quad 108$ final, http://ec.europa.eu/world/enp/docs/2012_enp_pack/e _pship_multilateral_en.pdf accessed on 14 October, 2012. 